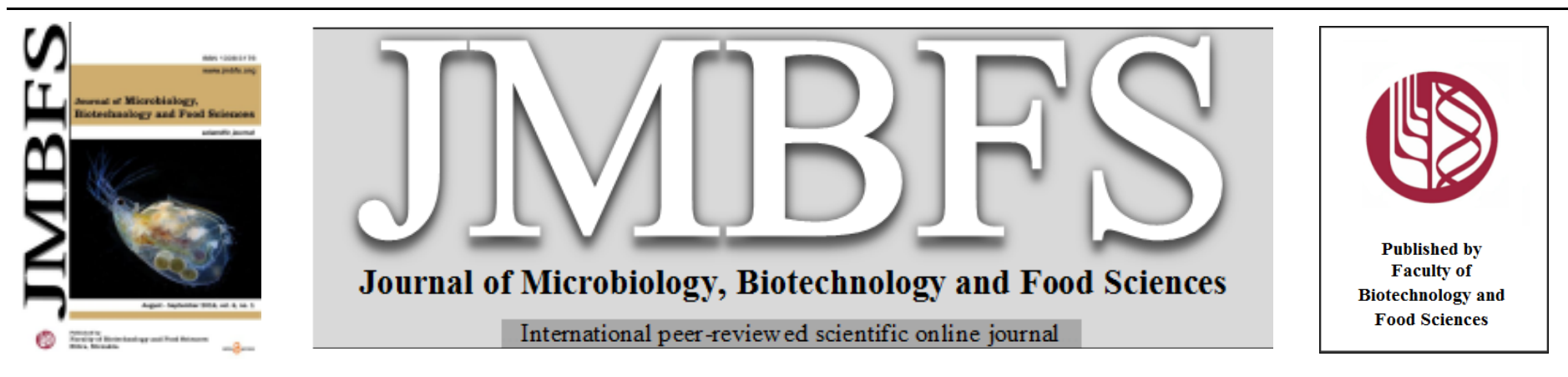

\title{
DETECTION OF MATERNAL COLONIZATION OF GROUP B STREPTOCOCCUS BY PCR TARGETING $C f b$ AND ScpB GENES
}

\author{
Marwa Fouad, Sahar Zakaria, Lobna Metwally, Hasan Aboul-Atta, Mahmoud Kamel
}

Address(es):

Department of Microbiology and Medical Immunology, Faculty of Medicine, Suez Canal University, Egypt.

*Corresponding author: saharmicrobiology@yahoo.com

doi: 10.15414/jmbfs.2016.6.1.713-716

\section{ARTICLE INFO}

Received 22. 10. 2015

Revised 22. 3. 2016

Accepted 14. 4. 2016

Published 1. 8. 2016

Regular article

OPEN $\partial_{\text {Access }}$

\begin{abstract}
Group B Streptococcus (GBS) is a leading cause of neonatal morbidity and mortality. Molecular based tests, such as polymerase chain reaction (PCR), can detect GBS within hours and can be used intrapartum allowing for selective intrapartum antibiotic prophylaxis (IAP) in women carrying GBS. The aim of this work was to evaluate PCR as a rapid screening method for detection of maternal colonization of GBS compared to culture. Vaginal/rectal swabs were collected from 120 pregnant women at 35-37 weeks of gestation and cultured on CNA medium. GBS was identified by gram staining and catalase, hippurate and CAMP tests and confirmed by latex agglutination for GBS antigens. PCR was done using two assays; one targeting the $c f b$ gene and the other targeting the $s c p$ B gene. Results revealed thatGBS colonization was detected in $15 \%, 23.3 \%$ and $21.7 \%$ of pregnant women by culture, $c f b$ PCR assay and $s c p B$ PCR assay respectively. $c f b$ PCR assay showed $100 \%$ sensitivity and $90.2 \%$ specificity whereas $s c p B$ PCR assay showed $94.4 \%$ sensitivity and $91.2 \%$ specificity. PCR could detect GBS genome at a concentration of as low as $10^{-2}$ for $c f b$ PCR and $10^{-3}$ for $s c p B$ PCR. In conclusion, PCR is a rapid, specific and sensitive tool for detection of maternal colonization of GBS. PCR assay targeting $s c p B$ gene is more sensitive than that targeting $c f b$ gene.
\end{abstract}

Keywords: Group B Streptococcus, polymerase chain reaction, pregnancy

\section{INTRODUCTION}

Vertical transmission of group B streptococcus (GBS) from a vagina colonized mother to her infant during labor can cause life-threatening infections in newborn. Maternal GBS colonization is associated with increased risk of transfer to the neonatal intensive care unit in term infants (Brigtsen et al., 2015). Neonatal sepsis and pneumonia are the most important GBS-related neonatal infections, followed by meningitis, celullitis, osteomyelitis and septic arthritis (Schrag et al., 2002). GBS is also associated with invasive and noninvasive infections in pregnant women and non-pregnant adults, especially the elderly or those with underlying medical conditions (Dutra et al., 2014).

The centers of disease control and prevention (CDC) recommended antenatal screening for all pregnant women at 35-37 weeks of gestation for the prevention of early onset GBS disease with vaginal/rectal cultures and selective IAP administration to GBS-positive women (CDC, 2010). Prenatal screening by culture is currently the gold standard method for detection of anogenital GBS colonization. However, cultures require several days (24-72 h) to yield results, thus precluding their use for intrapartum screening and these are only performed at 35-37 weeks gestation (Emonet et al., 2013). For this reason, there is a requirement for a rapid diagnostic test to detect GBS colonization status of women in labour, those in preterm labour or women who have not had prenatal care (Gavino and Wang, 2007).

An ideal screening test for GBS colonization is which could accurately identify pregnant women who carry the bacteria (even low-count bacteria carriers) and presenting a short turnaround time (de-Paris et al., 2011). New rapid molecularbased tests, such as polymerase chain reaction (PCR), can detect GBS within hours. They have the potential to be used intrapartum and to allow for selective IAP in women carrying GBS (Emonet et al., 2013). PCR assays have been developed to detect a variety of genetic targets, including genes encoding $\mathrm{C}$ protein, the 16S rRNA, and the 16S-23S spacer region (Bergeron and Ke, 2004). The objective of our study was to evaluate PCR targeting $c f b$ and $s c p B$ genes as a screening method for detection of maternal colonization of GBS compared to culture.

\section{MATERIAL AND METHODS}

\section{Detection of GBS by culture}

The study included 120 consenting pregnant women, between 35 and 37 weeks of gestation, attending the antenatal clinic of Suez Canal University Hospital in Ismailia, Egypt. Vaginal/rectal swabs were collected from each patient and inoculated into Lim broth; a selective medium consisting of Todd-Hewitt broth supplemented with $10 \mu \mathrm{g} / \mathrm{ml}$ colistin and $15 \mu \mathrm{g} / \mathrm{ml}$ nalidixic acid. Cultures are incubated at $37^{\circ} \mathrm{C}$ for 24 hours and then subcultured onto CNA medium (Colombia blood agar supplemented with $10 \mu \mathrm{g} / \mathrm{ml}$ colistin and $15 \mu \mathrm{g} / \mathrm{ml}$ nalidixic acid) and incubated at $37^{\circ} \mathrm{C}$ for 24 hours. Colonies with a narrow zone of beta hemolysis were suggestive of GBS and were further identified by being gram positive cocci, catalase negative, CAMP (Christie, Atkins, and MunchPeterson)positive and hippurate hydrolysis positive. Confirmation was done by a streptococcus latex agglutination test (BIOTEC Laboratories).

\section{Detection of GBS by PCR targeting $c f b$ and $s c p B$ genes}

All the 120 specimens were tested by PCR for detection of GBS using two sets of primers; one targeting the $c f b$ gene which encodes the CAMP factor and the other one targeting the $s c p B$ gene which encodes C5a peptidase.

After DNA extraction, PCR reaction for each assay was performed in a $25 \mu \mathrm{l}$ volume containing $2.4 \mu \mathrm{l}$ DNA template, $12.5 \mu \mathrm{l}$ of $2 \mathrm{X}$ power Taq PCR master mix (QIAGEN, Germany), $0.7 \mu \mathrm{M}$ of each primer. The volume for each PCR reaction was completed to $25 \mu \mathrm{l}$ with nuclease free water. For the $c f b$ PCR, primers published by Ke et al. (2000) were used. For the $s c p B$ PCR, the primers described by Dmitriev $\boldsymbol{e t}$ al. (2004) were used. The primer sequence and amplicon size for each target gene are shown in Table (1). A negative control consisting of the reaction mixture and nuclease-free water was added in each run. In addition, a reference $S$. agalactiae (ATCC 12386) strain was used as positive control. 
Table 1 Primer sequence and amplicon size for each target gene

\begin{tabular}{llc}
\hline Target gene & Primer Sequences & $\begin{array}{c}\text { Amplicon Size } \\
\text { (bp) }\end{array}$ \\
\hline \multirow{3}{*}{$\boldsymbol{c} \boldsymbol{b}$ gene } & 5'-TTTCACCAGCTGTATTAGAAGTA- & \\
& 3' & 153 \\
& 5'- GTTCCCTGAACATTATCTTTGAT- & \\
\multirow{2}{*}{$\boldsymbol{c} \boldsymbol{B} \boldsymbol{B}$ gene } & 5' & \\
& 5'-ACACATGGAAGGCTCTACTGTTC-3' & 225 \\
\hline
\end{tabular}

Amplifications were carried out in a Thermocycler (Eppendorf, USA) and consisted of initial denaturation step at $94^{\circ} \mathrm{C}$ for 3 minutes followed by 33 cycles of 45 seconds at $94^{\circ} \mathrm{C}, 45$ seconds at $57^{\circ} \mathrm{C}$, and one minute at $72^{\circ} \mathrm{C}$. These are followed by an extension step at $72^{\circ} \mathrm{C}$ for 7 minutes. The amplicons obtained were run on $2 \%$ agarose gel with $0.5 \mu \mathrm{g} / \mathrm{ml}$ ethidium bromide in a Tris-borateEDTA buffer. The gels were run in an electrophoresis gel tank at $100 \mathrm{~V}$ for 30 minutes. After electrophoresis the sizes of DNA fragments were calculated using 100 bp ladder as DNA molecular size standards. Each gel run contained a negative control and a positive control. Finally, the DNA was visualized and photographed using a Gel Documentation System (BioSpectrum 310 Imaging System, USA).

\section{Evaluation of PCR assay}

The specificity and sensitivity of PCR assay using the previously mentioned primers were evaluated compared to culture. The analytical sensitivity (i.e. the detection limit or the minimal number of genome copies that canbe detected) of each assay was determined by testing serial 10 -fold dilutions of purified genomic DNA from a reference GBS strain (ATCC 12386), containing from $10^{-1}$ to $10^{-7}$ $\mathrm{CFU} / \mathrm{ml}$ and starting with a concentration of $38.1 \mathrm{ng} / \mu \mathrm{l}$. The stock DNA concentration was measured using the nanodrop technique (NanoDrop ND-1000 spectrophotometer). Each 10-fold dilution was added directly to the PCR reaction mixture before PCR amplification for each of the $c f b$ and $s c p B$ genes Amplifications were carried out using the same conditions used in the two PCR assays carried out before. A negative control was included in the reaction for both genes. After gel electrophoresis, the DNA was visualized and photographed. The analytical sensitivity of each of the two PCR assays was determined as the least concentration of genomic DNA at which the PCR gave a detectable band.

\section{RESULTS AND DISCUSSION}

Eighteen samples out of 120 were identified as GBS by culture. The rate of maternal colonization of GBS by the culture method was $15 \%$. Twenty eight specimens $(23.3 \%)$ were positive for GBS using the $c f b$ PCR assay. Positive specimens showed specific bands of approximately 153bp in size (Figure 1). Twenty six specimens $(21.7 \%)$ were positive for GBS using the $s c p B$ PCR assay. Positive specimens showed specific bands of approximately $255 \mathrm{bp}$ in size (Figure 2).

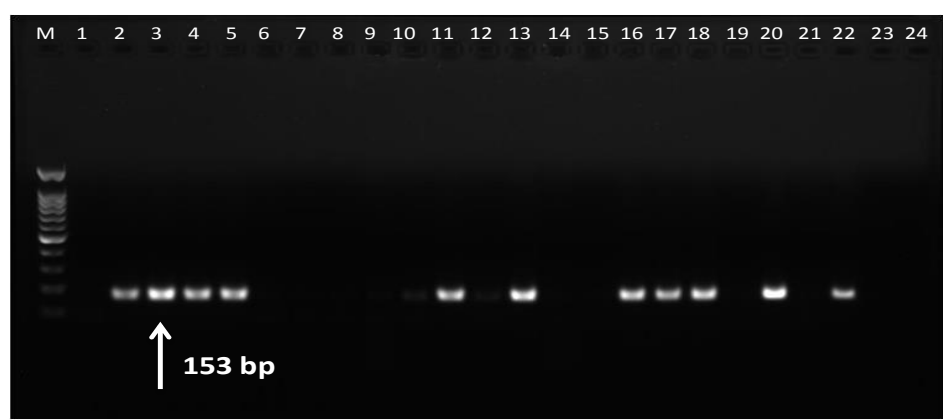

Figure (1) $c f b$ PCR assay (153 bp amplicon)

$\mathrm{M}$ is a $100 \mathrm{bp}$ DNA ladder, Lane 1 is a negative control, Lane 2 is a positive control; Lanes 3-24 are tested specimens

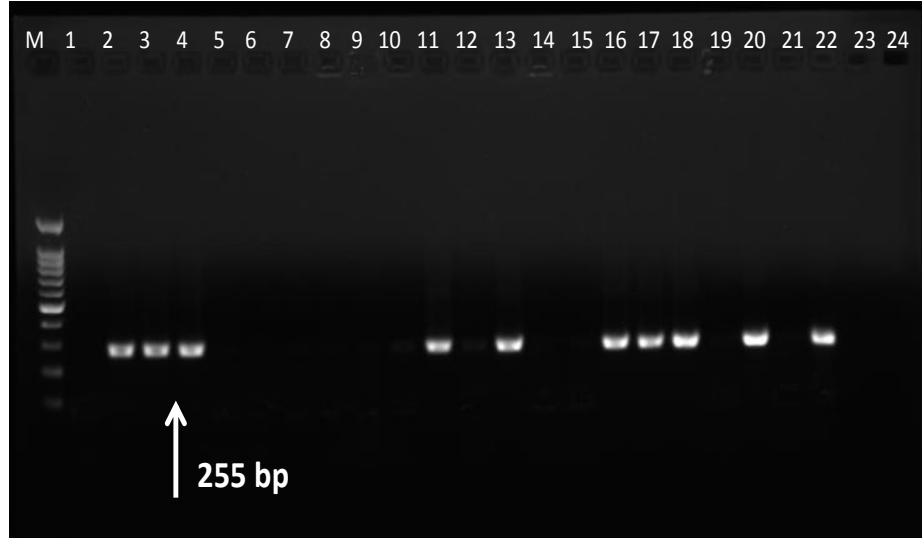

Figure (2) $s c p B$ PCR assay (255 bp amplicon)

$\mathrm{M}$ is a $100 \mathrm{bp}$ DNA ladder, Lane 1 is a negative control, Lane 2 is a positive control, Lanes 3-24 are tested specimens

All the eighteen culture positive specimens were also positive by the $c f b$ PCR assay while only 17 of them were positive by $s c p B$ PCR assay. Among the 102 culture negative specimens, 10 were positive by $c f b$ PCR assay while 9 were positive by $s c p B$ PCR assay. In comparison to the culture method, the $c f b$ PCR assay exhibited $100 \%$ sensitivity and $90.2 \%$ specificity with a positive predictive value of $64.3 \%$ and a negative predictive value of $100 \%$ whereas the scpB PCR assay revealed $94.4 \%$ sensitivity and $91.2 \%$ specificity with a positive predictive value of $65.4 \%$ and a negative predictive value of $98.9 \%$. On determining the detection limit of PCR, it was found that both $c f b$ and $s c p B$ PCR assays were able to detect GBS DNA at a concentration of $0.01\left(10^{-2}\right)$, but the $c f b$ PCR assay was slightly more sensitive being able to detect GBS DNA at a lower concentration (one $\log 10$ difference; $10^{-3}$ ) (Figure 3).

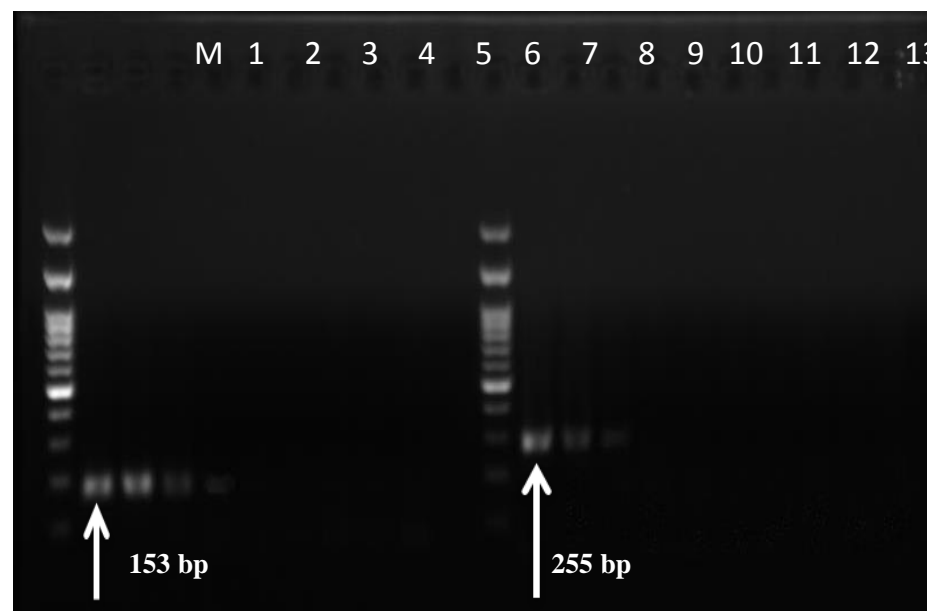

Figure (3) Detection limits of $c f b$ PCR assay (153 bp amplicon)and $s c p$ B PCR assay (255 bp amplicon)

M \& lane 11 are 100 bp DNA ladder, Lanes $1 \& 12$ are neat DNA, Lanes 2-9 \& 13-20 are serial 10-fold dilutions of DNA extract, Lanes $10 \& 21$ are negative control

Although culture methods are the current standard for prenatal GBS screening, the implementation of more sensitive molecular diagnostic tests may be able to further reduce the risk of early-onset GBS infection (Buchan et al., 2015). Using the culture method, this study reported that the rate of GBS colonization in pregnant women was $15 \%$. This rate varies greatly among countries. It was reported to be $7.98 \%$ in Italy (Puccio et al., 2014), 7.2\% in Ethiopia (Woldu et al., 2014), 14\% in Denmark (Peterson et al., 2014), 20\% in USA (Page-Ramsey et al., 2013), $21.8 \%$ in Taiwan (Lee and Lai, 2014), $20.7 \%$ in Kuwait and $18.4 \%$ in Lebanon (Ghaddar et al., 2014). These variations in colonization rates relate to intrinsic differences in populations and to lack of standardization in culture methods employed for ascertainment, Also, a change in the prevalence over time, or real population differences account for some of the disparity in these reported prevalence rates. In spite of the great variation of prevalence rates, Le and Heath (2013) reported that the serotype distribution of GBS isolates is similar in Africa, Western Pacific, Europe, the Americas and the Eastern Mediterranean regions and has not changed over the past 30 years.

This study showed that PCR using $c f b$ and $s c p B$ genes was more sensitive for detection of GSB than the culture method as the rate of detection was $15 \%$ by the culture method compared to $23.3 \%$ by $c f b$ PCR assay and $21.7 \%$ by $s c p B$ PCR 
assay. A previous study done in Egypt by Shabayek et al. (2009) reported that GBS was detected in $25.3 \%$ of isolates by culture, $30.6 \%$ by $c f b$ PCR assay and $30 \%$ by $s c p B$ PCR assay. Bakhtiari et al. (2012) found out that the frequencies of GBS carriage were $9.3 \%$ by the culture method and $11.2 \%$ by a PCR assay targeting $c f b$ gene.

The increased sensitivities of GBS-specific PCR assays over the culture method could have many explanations; a possible explanation may be the presence of nonviable GBS that could be detected by PCR but not by culture, as well as inability of culture to detect low bacterial numbers. Suppression of GBS growth by Enterococcus fecalis that exist in the vaginal flora (antagonistic phenomenon) has also been documented (Park et al., 2001). Antibiotics and feminine hygiene products have also shown to interfere with the detection of GBS by culture but have no detrimental effect on PCR (Ostroff and Steaffens, 1995). Inadequate specimen collection and transport from obstetrical clinics to the laboratory may have some effect especially in case of light colonization (Rosa-Fraile et al., 2005).

Great sensitivity, high negative predictive value and rapid results are desirable parameters of a screening test. In our study, the sensitivities of $c f b$ and $s c p B$ PCR assays were $100 \%$ and $94.4 \%$ respectively. In the study of Rallu et al. (2006), their sensitivities were $75.3 \%$ and $99.6 \%$ respectively. Goudarzi et al. (2015) reported PCR sensitivity $72.2 \%$. The high sensitivity in our study is probably attributed to the use of selective and enriched broth media previous to performing the PCR.

The negative predictive values were $100 \%$ and $98.9 \%$ for $c f b$ and $s c p B$ PCR assays respectively, which were similar to the findings of de-Paris et al. (2011)who reported a negative predictive value of $100 \%$. This finding is important because it indicates that all samples with negative results are truly negative, which affords to safely with hold treatment from women presenting PCR negative samples. This is so important in clinical routine because false negative results in a screening test may lead to serious consequences for the patient, considering that this test is used to take a decision about antibiotic prophylaxis.

The specificities were found to be $90.2 \%$ and $91.2 \%$ for $c f b$ and $s c p B$ PCR assays respectively. These were less than the $95.65 \%$ reported by Mulleur et al. (2014) and the 100\% reported by Daher et al. (2014). However, even being considered the gold standard, culture results can be false negative. It is known that culture may not be absolutely effective in the detection of GBS, since other bacteria of the genital tract can inhibit the growth of GBS even when using the selective broth. So, the supposedly false positive results in PCR may actually indicate the presence of GBS in the studied material, since this is an analytical technique whose sensitivity could be greater than the bacteriological examination. The gold standard performance affects the positive predictive value parameter. In this study the positive predictive value was $64.3 \%$ and $65.4 \%$ for $c f b$ and $s c p B$ PCR assays respectively compared to the $59 \%$ found by de-Paris $\boldsymbol{e t}$ al. (2011). Regarding the analytical sensitivity assessment of PCR assays, it was evident that the $c f b$ PCR assay was slightly more sensitive being able to detect GBS DNA at a lower concentration $\left(10^{-3}\right)$ than that detected by the $s c p B$ PCR assay $\left(10^{-2}\right)$.

The PCR assays in this study required about 100 minutes for sample processing, PCR amplification, and gel electrophoresis and even with using a previous incubation in selective broth, it required 24 hours to give the final result. This offers an advantage over the culture method which is a time-consuming method requiring at least 48 hours for full GBS identification.

\section{CONCLUSION}

Although more expensive than the standard culture method, the PCR technique targeting $c f b$ and $s c p B$ genes is rapid, specific and has a higher sensitivity in detecting GBS carriers during pregnancy with the $s c p B$ PCR assay being more sensitive than the $s f b$ PCR assay. PCR allows for accurate diagnosis of GBS which will be translated into more rational use of antibiotics and more effective treatment of carrier females leading to reduction of newborn morbidity and mortality. Yet, the cost-effectiveness of such PCR tests need to be more elucidated by further studies to see if it can be used as a routine screening method in centers with maternity wards.

\section{REFERENCES}

BAKHTIARI, R., DALLAL, MS., MEHRABADI, J., HEIDARZADEH, S. AND POURMAND, M. 2012. Evaluation of culture and PCR methods for diagnosis of groupB streptococcus carriage in Iranian pregnant women. Iran $\mathbf{J}$ Public Health, 41(3), 65-70.

BERGERON, MG., KE, D. 2004. New DNA-Based PCR approaches for rapid real-time detection and prevention of Group B Streptococcal infections in newborns and pregnant women. Reprod Med Rev, 11, 25 41.http://dx.doi.org/10.1017/s1462399401003805

BRIGTSEN, AK., JACOBSEN, AF., DEDI, L., MELBY, KK., FUGELSETH, D., WHITELAW A. 2015.Maternal Colonization with Group B Streptococcus Is Associated with an Increased Rate of Infants Transferred to the Neonatal $\begin{array}{llll}\text { Intensive Care Unit. } & \text { Neonatology. }\end{array}$ 163.http://dx.doi.org/10.1159/000434716
BUCHAN, BW., FARON, ML., FULlER, D., DAVIS, TE., MAYNE, D. LEDEBOER, NA. 2015. Multicenter clinical evaluation of the Xpert GBS LB assay for detection of group B Streptococcus in prenatalscreening specimens. Clin Microbiol, 53(2), 443-8. http://dx.doi.org/10.1128/jcm.02598-14

(Centers for Disease Control and Prevention). 2010. Prevention of Perinatal Group B Streptococcal Disease. MMWR Morb Mortal Wkly Rep, 59:( RR-10), $1-32$.

DAHER, RK., STEWART, G., BOISSINOT, M.,BERGERON, MG.2014. Isothermal recombinase polymerase amplification assay applied to the detection of groupBstreptococci in vaginal/anal samples. Clin Chem, 60(4), 660-6. http://dx.doi.org/10.1373/clinchem.2013.213504

de-PARIS, F., MACHADO, AB., GHENO, TC., ASCOLI, BM., OLIVEIRA, KRPD., BARTH, AL. 2011. Group B Streptococcus detection: comparison of PCR assay and culture as a screening method for pregnant women. Braz J Infect Dis, 15(4), 323-327.http://dx.doi.org/10.1590/s1413-86702011000400004 DMITRIEV, A., SUVOROV, A., SHEN, AD., YANG, YH. 2004. Clinica diagnosis of group B streptococci by scpB gene based PCR. Indian J Med Res, 119 (Suppl):233-6.

DUTRA, VG., ALVES, VMN., OLENDZKI, AN., DIAS, CAG., DE BASTOS AFA., SANTOS, GO., DE AMORIN, ELT., SOUSA, MÂB., SANTOS, R., RIBEIRO, PCS., FONTES, CF., ANDREY, M., MAGALHÃES, K., ARAUJO, AA., PAFFADORE, LF., MARCONI, C., MURTA, EFC., FERNANDES, JPC., RADDI, MSG., MARINHO, PS., BORNIA, RBG., PALMEIRO, JK., DALLACOSTA, LM., PINTO, TCA., BOTELHO, AN., TEIXEIRA, LM. FRACALANZZA, SEL. 2014. Streptococcus agalactiae in Brazil: serotype distribution, virulence determinants and antimicrobial susceptibility. BMC Infect Dis, 14, 323.http://dx.doi.org/10.1186/1471-2334-14-323

EMONET, S., SCHRENZEL, J., MARTINEZ DE TEJADA, B. 2013. Molecularbased Screening for Perinatal Group B Streptococcal Infection: Implications for Prevention and Therapy. Mol Diagn Ther, 17, 355-361. http://dx.doi.org/10.1007/s40291-013-0047-2

GAVINO, M., WANG, E. 2007. A comparison of a new rapid real-time polymerase chain reaction system to traditional culture in determining group B Streptococcus colonization. Am J Obstet Gynecol, 197, 388e1-388e4. http://dx.doi.org/10.1016/j.ajog.2007.06.016

GHADDAR, N., ALFOUZAN, W., ANASTASIADIS, E., AL JISER, T., ITANI, SE., DERNAIKA, R., EID, T., GHADDAR, A., CHARAFEDDINE, A., DHAR, R., EL HAJJ, H. 2014.Evaluation of chromogenic medium and direct latex agglutination test for detection of group B streptococcus in vaginal specimens from pregnant women in Lebanon and Kuwait. J Med Microbiol, 63(Pt 10), 1395-9. http://dx.doi.org/10.1099/jmm.0.066738-0

GOUDARZI, G., GHAFARZADEH, M., SHAKIB, P., ANBARI, K 2015. Culture and Real-Time PCR Based Maternal Screening and Antibiotic Susceptibility for Group B Streptococcus: An Iranian Experience. Glob J Health Sci, 7(6), 45075. http://dx.doi.org/10.5539/gihs.v7n6p233

KE, D., MENARD, C., PICARD, FJ., BOISSINOT, M., OUELlETTE, M., ROY,PH., BERGERON, MG. 2000. Development of conventional and real-time PCR assays for the rapid detection of group B streptococci. Clin Chem, 46(3), 324-31.

LE DOARE, K., HEATH, PT. 2013.An overview of global GBSepidemiology. Vaccine,31 Suppl 4, D7-12. http://dx.doi.org/10.1016/j.vaccine.2013.01.009

LEE, WT., LAI, MC. 2014. High prevalence of Streptococcus agalactiae from vaginas of women in Taiwan and its mechanisms of macrolide and quinolone resistance. J Microbiol Immunol Infect, (14)000553.http://dx.doi.org/10.1016/j.jmii.2014.03.002

MUELlER, M., HENLE, A., DROZ, S., KIND, AB., ROHNER, S., BAUMANN, M., SURBEK, D. 2014.Intrapartum detection of GroupBstreptococci colonization by rapid PCR-test on labor ward.Eur J Obstet Gynecol Reprod Biol,176, 137-41.http://dx.doi.org/10.1016/j.ejogrb.2014.02.039 OSTROFF, RM., STEAFFENS, JW. 1995. Effect of specimen storage, antibiotics, and feminine hygiene products on the detection of Group B Streptococcus by culture and the STREP B OIA test. Diagn Microbiol Infect Dis, 22, 253-9.http://dx.doi.org/10.1016/0732-8893(95)00046-d

PAGE-RAMSEY, SM., JOHNSTONE, SK., KIM, D., RAMSEY, PS. 2013 Prevalence of group B Streptococcus colonization in subsequent pregnancies of group B Streptococcus-colonized versus noncolonized women.Am J Perinatol, 5, 383-8. http://dx.doi.org/10.1055/s-0032-1326981

PARK, CH., VANDEL, NM., RUPRAI, DK., MARTIN, EA., GATES, KM. COKE, D. 2001. Detection of Group B Streptococcal colonization in pregnant women using direct latex agglutination testing of selective broth. J Clin Microbiol, 39, 408-9.http://dx.doi.org/10.1128/jcm.39.1.408-409.2001 PETERSEN, KB., JOHANSEN, HK., ROSTHØJ, S., KREBS, L., PINBORG, A., HEDEGAARD, M. 2014.Increasing prevalence of group B streptococcal infection among pregnant women. Dan Med J, 61(9), A4908.

PUCCIO, G., CAJOZZO, C., CANDUSCIO, LA., CINO, L., ROMANO, A., SCHIMMENTI, MG., GIUFFRÈ, M., CORSELLO, G. 2014. Epidemiology of Toxoplasma and CMV serology and of GBS colonization in pregnancy and neonatal outcome in a Sicilian population. Ital $\mathbf{J}$ Pediatr, 40, 23 http://dx.doi.org/10.1186/1824-7288-40-23 
RALLU F, BARRIGA P, SCRIVO C, MARTEL-LAFERRIÈRE V, LAFERRIÈRE C.2006. Sensitivities of antigen detection and PCR assays greatly increased compared to that of the standard culture method for screening for group B Streptococcus carriage in pregnant women. J Clin Microbiol, 44(3), 725728.http://dx.doi.org/10.1128/jcm.44.3.725-728.2006

ROSA-FRAILE, M., CAMACHO-MUNOZ, E., RODRIGUEZ-GRANGER, J., LIÉBANA-MARTOS, C. 2005.Specimen storage in transport medium and detection of Group B Streptococci by culture. J ClinMicrobiol, 43, 928 930.http://dx.doi.org/10.1128/jcm.43.2.928-930.2005

SCHRAG, S., GORWITZ, R., FULTZ-BUTTS, K., SCHUCHAT, A. 2002.

Prevention of perinatal group B streptococcal disease. Revised guidelines from CDC. Morb Mortal Wkly Rep RecommRep, 51, 1-22.

SHABAYEK, S., ABDALLA, S., ABOUZEID, A. 2009. Vaginal carriage and antibiotic susceptibility profile of Group B Streptococcus during late pregnancy in Ismailia, Egypt. J Infec Public Health, 2, 8690.http://dx.doi.org/10.1016/j.jiph.2009.03.004

WOLDU, ZL., TEKLEHAIMANOT, TG., WAJI, ST., GEBREMARIAM, MY.

2014. The prevalence of Group B Streptococus recto-vaginal colonization and antimicrobial susceptibility pattern in pregnant mothers at two hospitals of Addis Ababa, Ethiopia.Reprod Health, 11, 80. http://dx.doi.org/10.1186/1742-4755-11$\underline{80}$ 